$2 / 3-13 / 82=1730$

\title{
Division 1137 Property Control System
}

\section{NOTICE}

PORTIONS OF THIS REPORT ARE ILLEGIBLE. It has been regroduced from the best avallable copy to permit the broadest possible avail-

Douglas J. Pastor ability.

Prepared by

Sandia National Laboratories

Albuquerque, New Mexico 87185 and Livermore, California 94550

for the United States Department of Energy

under Contract DE-ACO4-76DP00789 


\section{DISCLAIMER}

This report was prepared as an account of work sponsored by an agency of the United States Government. Neither the United States Government nor any agency Thereof, nor any of their employees, makes any warranty, express or implied, or assumes any legal liability or responsibility for the accuracy, completeness, or usefulness of any information, apparatus, product, or process disclosed, or represents that its use would not infringe privately owned rights. Reference herein to any specific commercial product, process, or service by trade name, trademark, manufacturer, or otherwise does not necessarily constitute or imply its endorsement, recommendation, or favoring by the United States Government or any agency thereof. The views and opinions of authors expressed herein do not necessarily state or reflect those of the United States Government or any agency thereof. 


\section{DISCLAIMER}

Portions of this document may be illegible in electronic image products. Images are produced from the best available original document. 
Issued by Sandia National Loboratories, operated for the United States Department of Energy by Sandia Corporation.

NOTICIE: This report was prepazed as an sccount of work sponsored by an agency of the Unitod States Government. Neither the United States Government nor any agency thereof, nor any of their omployees, nor any of their ment nor any agency thereol, nor any ol their mployen, warranty, expreas contractors, subcontractors, or their employes, mases any warranty, expreas
or implied, or aseumes any legal liability or regponsibility for the accuracy, completenese, or usefuluess of any information, apparates, product, or process disclosed, or represents that its use would not infringe privatoly owned rights. Reference harein to any specific commercial product, process, or service by trade name, trademark, manufacturer, or otherwise, does not necessarily constitute or imply its endorsement, recommendation, or favoring by the United States Government, any agency thereof or any of their by the lon or subatin contractors or subcontractors. The views and opinions expressed herein do not necessarily state or reflect those of the United States Government, any agency thereof or any of their contractors or subcontractors.

Printed in the United States of America Available from

National Technical Information Service

U.S. Department of Commerce

5285 Port. Royral Rouad

Springrield, VA 22161

NTIS price codes

Printed copy: A0s

Mierofiche copy: A01 


\section{Division 1137 Property Control System}

Douglas J. Pastor

Mobile and Remote Ranges Division 1137

Sundin National Laboratories

Albuquerque, NM 87185

\section{Abstract}

An automated data processing property control system was developed by Mobile and Reunte Range Division 1137. This report deocribes the operation of the system and examines ways of using it in operational planning and control.

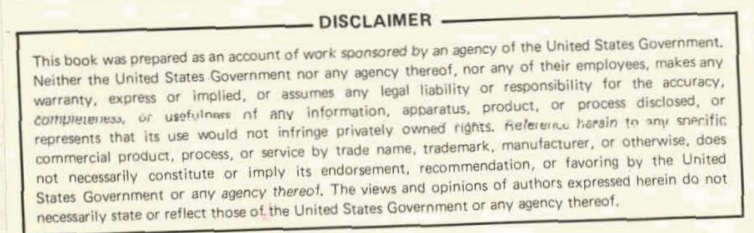




\section{Acknowledgment}

R. D. Pace, Supervisor 1137-1, and E. D. Stout, Supervisor 1137-2, provided invaluable assistance in the development and implementation of this property control system. 


\section{Contents}

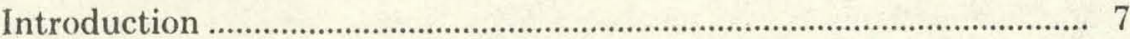

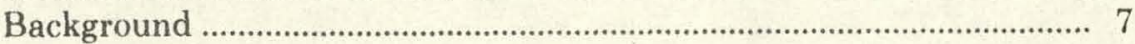

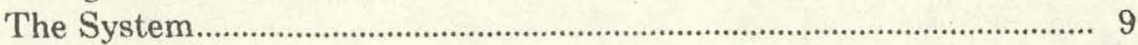

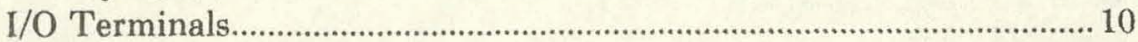

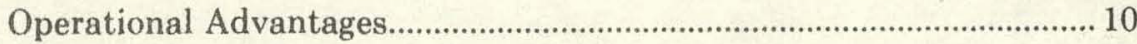

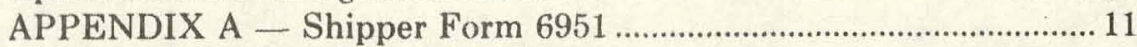

APPENDIX B - Example of Format of Full Inventory Tab Run Sorted by Description and Serial Number ............................................. 13 APPENDIX C - Examples of Full Inventory Tab Runs for Various Priorities .15 APPENDIX D - Examples of Full Inventory Search Tab Runs for

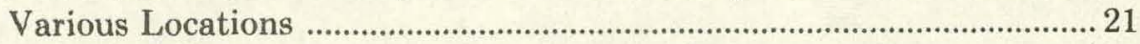

APPENDIX E - Division 1137, Property Movement Form ............... 23 APPENDIX F - Examples of Errors Discovered by the Movement Fill Routine .25 APPENDIX G - Listings for Various Movements of Equipment..... 27 APPENDIX $\mathrm{H}$ - Example of Format of Tab Run Listing All Items in a Single Location (Shipper Format)

APPENDIX I - Block Dump Inventory ………..................................... 33

\section{Figure}

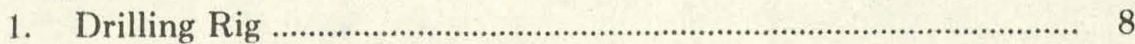

2. Interior of Equipment Trailer ……............................................ 8

3. Example of Division 1137 Control Number (Left) and Sandia S-Number (Right) 


\section{Division 1137 Property Control System}

\section{Introduction}

This report describes the automated data processing (ADP) property control system developed by Mobile and Remote Ranges Division 1137. It explains the special circumstances which created a need for such a system, tells how it operates, and examines ways the system can be used in operational planning and control.

The system is based on open network operating system (NOS) time sharing and consists of two data files and software routines for processing the information in forms which uniquely serve Division 1137's needs. Besides the customary inventory location data, the system stores a complete and permanent record of property movement. Input techniques and output formats were designed specifically to engage the participation of division members most directly involved with operation of the equipment.

Neither this document nor the system it describes addresses employee responsibilities for the physical protection of DOE/SNL property. Rather, the system is presented as an aid to more effective and efficient property management under extraordinary circumstances. Although the major reason for initiating development of the system was to gain a more opecialized means of property control, its features promise to be very beneficial operationally; e.g., budgetary information stored for each item includes acquisition costs, replacement cost, purchase order number, acquisition date and estimated replacement date. Equipment cost figures are readily available and can be used in preparation of the Assets Protection Security Plan which must accompany each move to a remote location. Other operational advantages are described below.

\section{Background}

Mobile and Remote Ranges Division 1137 supports weapons development, weupon-related reimbursable programs, and, to a minor extent, energyrelated test activity throughout the United States and abroad. The division is responsible for more than 2000 controlled items, including telemetry receiving, recording, and data processing equipment; rotary drilling rigs and ancillary equipment; special purpose vehicles; fixed and mobile field radios; and a wide variety of electrical, mechanical, optical, and related devices required to support high technology field operations in remote areas (Figures 1 and 2).

The nature of remote site field testing mandates frequent material movement, ranging from individual items to blocks of several hundred. The destination might be a test range, a military base, a contractor's plant, or an undeveloped remote area. The property may remain at the new location for a week, a month or several years.

Test support ordinarily involves one or more instrumentation trailers or vans containing a large number of controlled items. A move is documented by listing the items on Shipper Form 6951 (Appendix A). When the Shipper is processed, the pertinent information is loaded into the SNLA Property Management System (PMS). Unfortunately, despite the best efforts of all organizations involved, the PMS has been unable to provide timely information about division 113 '/'s inventory. Uften, PMS outputs data which lag actual events by several moves. Such obsolete information can have obvious effects on spot audits, inventory surveys, and other aspects of property accounting.

A heavy test schedule and the consequent large number of moves increased the level of technical manpower devoted to record keeping. Early in FY81, Division 1137 began development work on a property control system tailored to the special needs of a highly mobile organization with a large inventory of accountable equipment. The objectives were to design a system which would (1) output up-to-date information on the movement and location of the division inventory, and (2) accept information at a minimum cost in technical manpower. From the outset, a design goal was a system which would perform an operational role, as well as the property control and assets protection functions. 


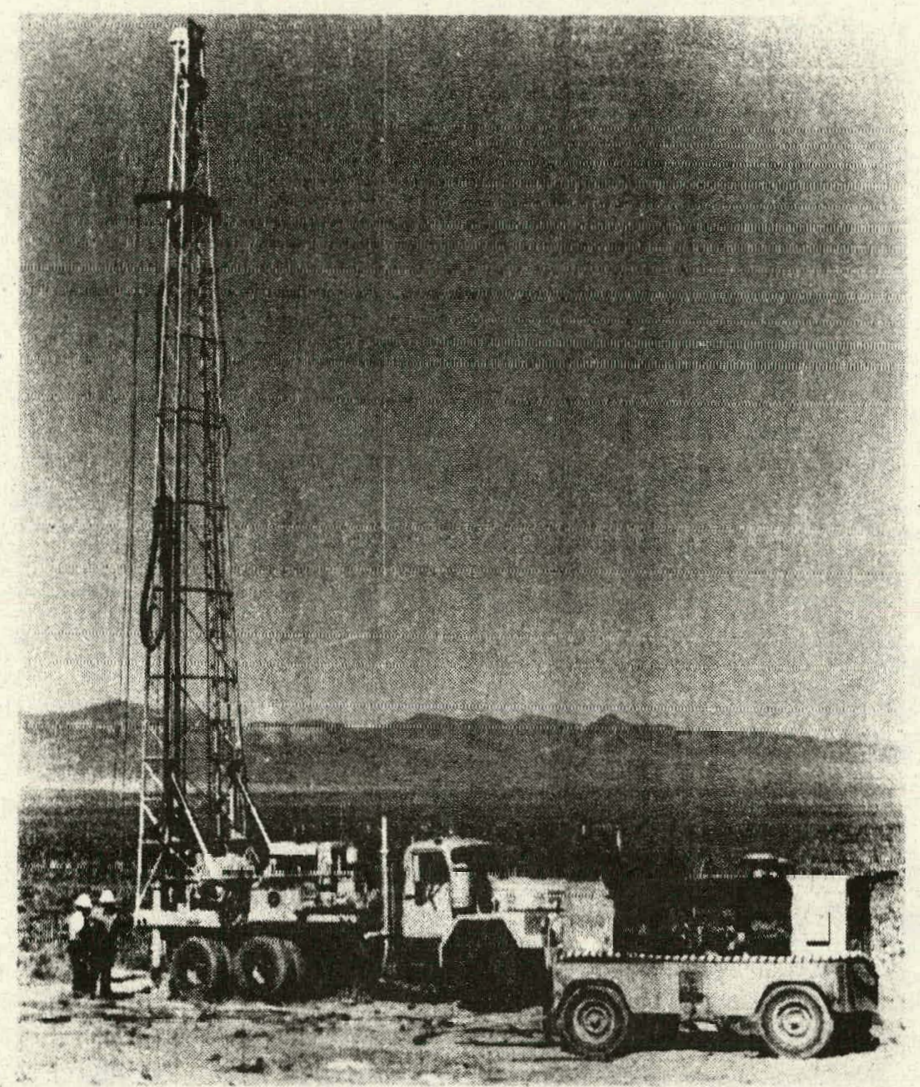

Figure 1. Drilling Rig

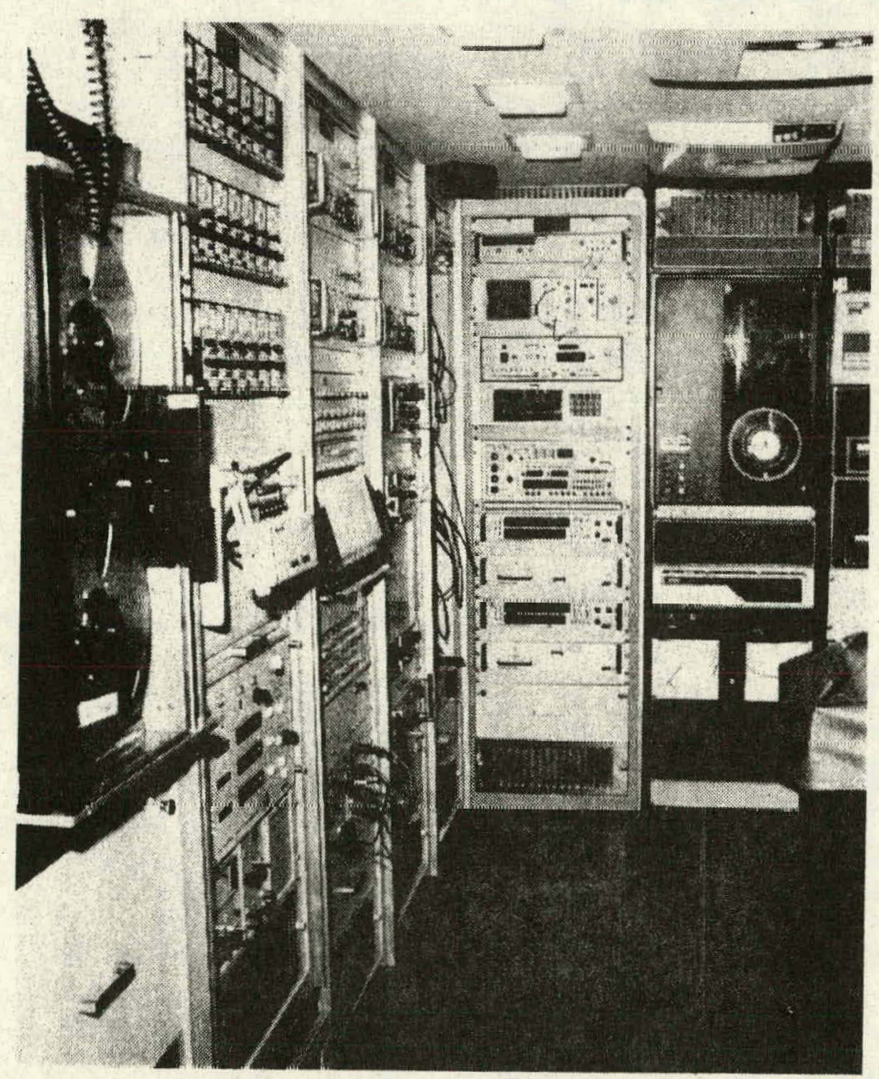

Figure 2. Interior of Equipment Trailer 


\section{The System}

'The central element of the system is the Master liventony Hile (MII) which is compiled fium divisiun records and updated as necessary. MIF lists all B, L, IR and S numbered property as well as several hundred pieces of uncont rolled equipment. Uncontrolled items are included when they are sensitive, critical for test support, expensive/difficult to replace, or are prone to recurrent movement; for example, subcarrier discriminator channel selectors are not recorded in PMS but are assigned division control numbers and listed in the master file. Figure 3 shows both types of propert.y numbers. As many as 10 pieces of information are stored against each control number (for example, description, model, manufacturer, cost, etc). All items in the file are assigned to a particular location such as an instrumentation trailer, shop area, or office.

Appendix $B$ shows an example of the tab run format generated when a full tab run of the entire inventory is reguested. Sorting is accomplished in the following order of preference:

\section{I) sise \\ MF(: \\ M()ISil,

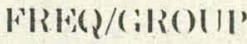

Serial Number

l'roperty Number

(or $11: 37$ assigned number)

po)

\section{I,OC:A,ITON}

Name, including lopic and subtopric; (example: tuner, S-band

Manufacturer

Frequency-related or functional-related information

Purchase order number

If a different sorting criterion is desired, any one of the categories shown above can be selected for first sorting priority and the entire inventory or a specific location sorted accordingly (Appendix C). Since equipment users furnish a running update on status, data in the system files will be the latest available. The full tah run is the primary instrument for property management, and the listings serve as a cross check to PMS information during audits. In addition, the inventory can be searched for a specific item or category of items, according to seven search options. The available search options are listed below.

- Topic:

- SIB-TOPIC.

- MFG:

Name

- MOI)EL, \#

- HRH(2)/GRUUP

- Property Number (or $11: 37$ assigned number)

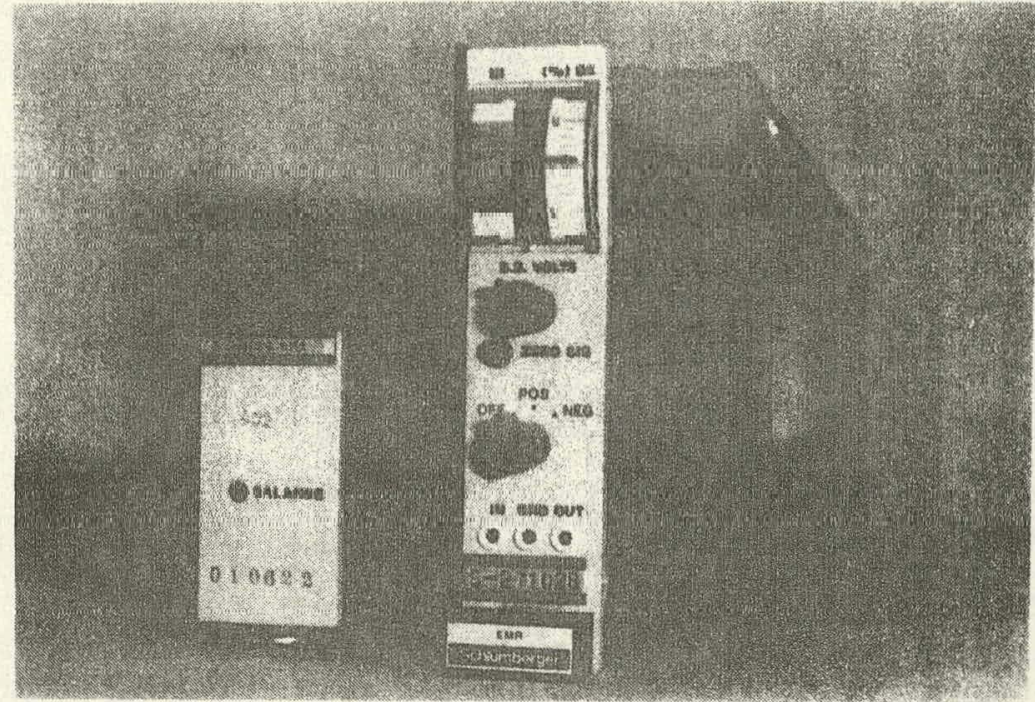

Figure 3. Example of Division 1137 Control Number (Left) and Sandia S-Number (Right)

- IP) H

Purchase order number

Several options can be combined to sort the file to a smaller sample, as in the case of DFSC, MFG, MODELL. If the entire inventory is not of interest, individual locations can be searched, (Appendix I)).

The other system file is designated Master Movement File (MMF). It includes only items inputted since the system came on-line. Property items are listed in MMF whenever they are moved. As many as nine pieces of information are supplied with each entry and collated with the MIF. Appendix E illustrates the input format (Property Movement Form) used for property movement. On entry, the information is compared with the data base in the MIF. Appendix $\mathrm{F}$ contains examples of errors discovered by the movement fill routine. ${ }^{*}$ Each item in the MMF can be traced through its history of movement. Movement may be traced under the following options:

Serial and Property Number

Description (all items of the same description)

Location (to or from a location)

Manufacturer

Model Number

FREQ/(IROUI)

Fimployee (all moves initiated by an emplover)

The printout can provide a history of all movement. movement during a specified period, or only moves in process (active entries) (Appendix (i).

*When inconsistencies are indicated, the key punch form is checked for incorrect information. 
When a block of items such as an instrumentation trailer is moved, the system will produce an up-todate list of all trailer items in a shipper format to be attached to Shipper 6951 (Appendix H). Although several hundred items may be involved, entry of only the trailer designator (example: B-42) will result in an output of the entire trailer inventory in the shipper format.

\section{I/O Terminals}

Two terminals are provided: one in the Division 1137 office at SNLA and one in Building 402 (KAFB Operations Section). Each terminal consists of

- CR'T 'Terminal

- Hard-Copy Line Printer

- 1200 Baud Modem/Accoustic Coupler

- Telephone for connection with NOS

- Entry Log Book (Movement. Data Keypunch Forms).

The terminal in Building 402 includes a telephone recorder.

When a move is initiated from a remote location, the information is called in to the telephone recorder; recorded messages are transcribed daily to the Movement Data Keypunch Form. When the move begins in the KAFB area, the employee responsible for the move registers the information on the keypunch form. 'The information on the keypunch forms is entered directly from either CRT terminal.

For most routines, three output options are available: hard copy at the user's local terminal, line printer output via SNLA computer annex, and microfiche output via SNLA's computer annex. Changes, additions, and deletions to the master file are entered from the terminals.

\section{Operational Advantages}

The foregoing has described the Division 1137 system primarily in its role of property accounting. Fortunately, many worthwhile features "fall out" at no additional cost. Some of the outputs which aid in operational planning and control were mentioned earlier. Others are

- Block dump inventory to determine completeness of station moving to field support location (Appendix I)

- Track and location of items which the block dump indicates are missing from a station

- A running tabulation of return due dates for items on loan or in repair

- Inventory search for scarce items which must be found quickly

- Iventory search for specific types of equipment needed in large numbers

- Rapid location of uncontrolled spare parts. For example, the channel selectors mentioned earlier are given Division 1137 control numbers and tagged with individual frequencies, making it easy to find a particular module quickly.

Software is being developed which will enable the system to track equipment failures. Such data will be used to furnish a performance history of a particular item, model, or class of equipment. Or, a station tab run will quickly identify the known equipment problems at a station.

As of November 1981, system design is complete and approximately $70 \%$ of the system is on-line. All elements will be operational by January, 1982 . If additional information is desired, the author can be contacted in Division 1137. 


\section{APPENDIX A}

Shipper Form 6951 


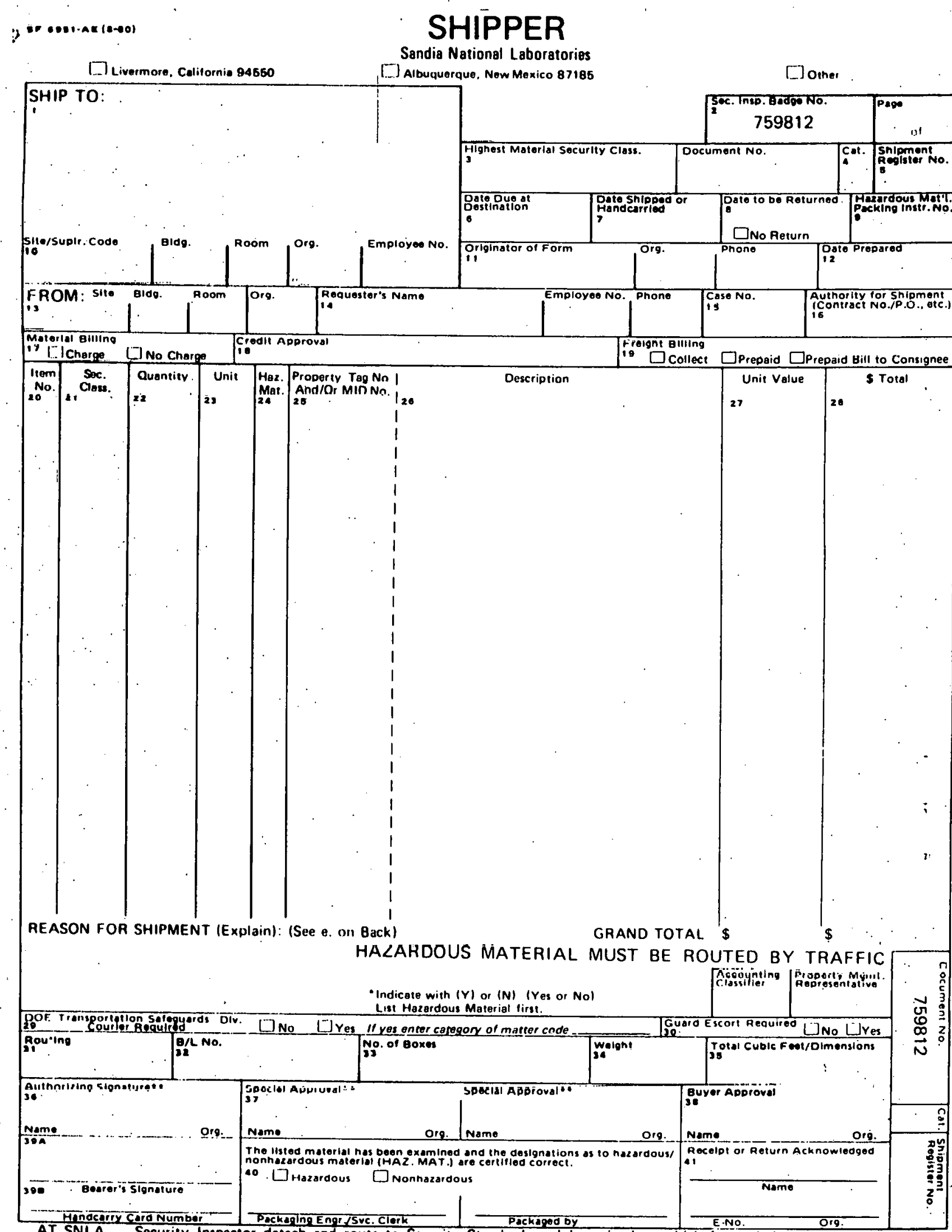
AT SNLA - Security Inspector detach and route to Security Standards and Investigations which forwards it to

AT SNLL - Corporate File in Purchasing 


\section{APPENDIX B}

Example of Format of Full Inventory Tab Run Sorted by Description and Serial Number 


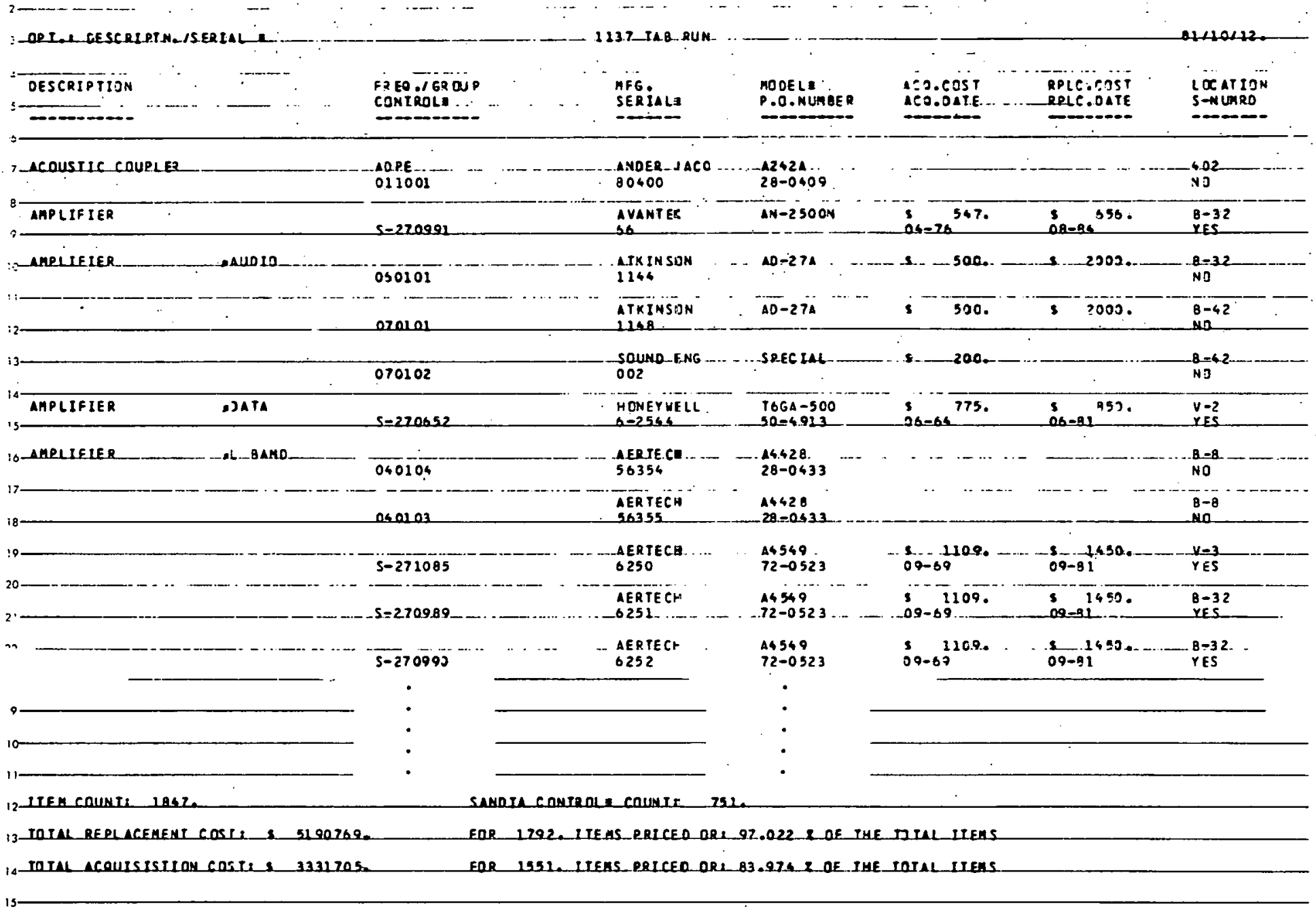




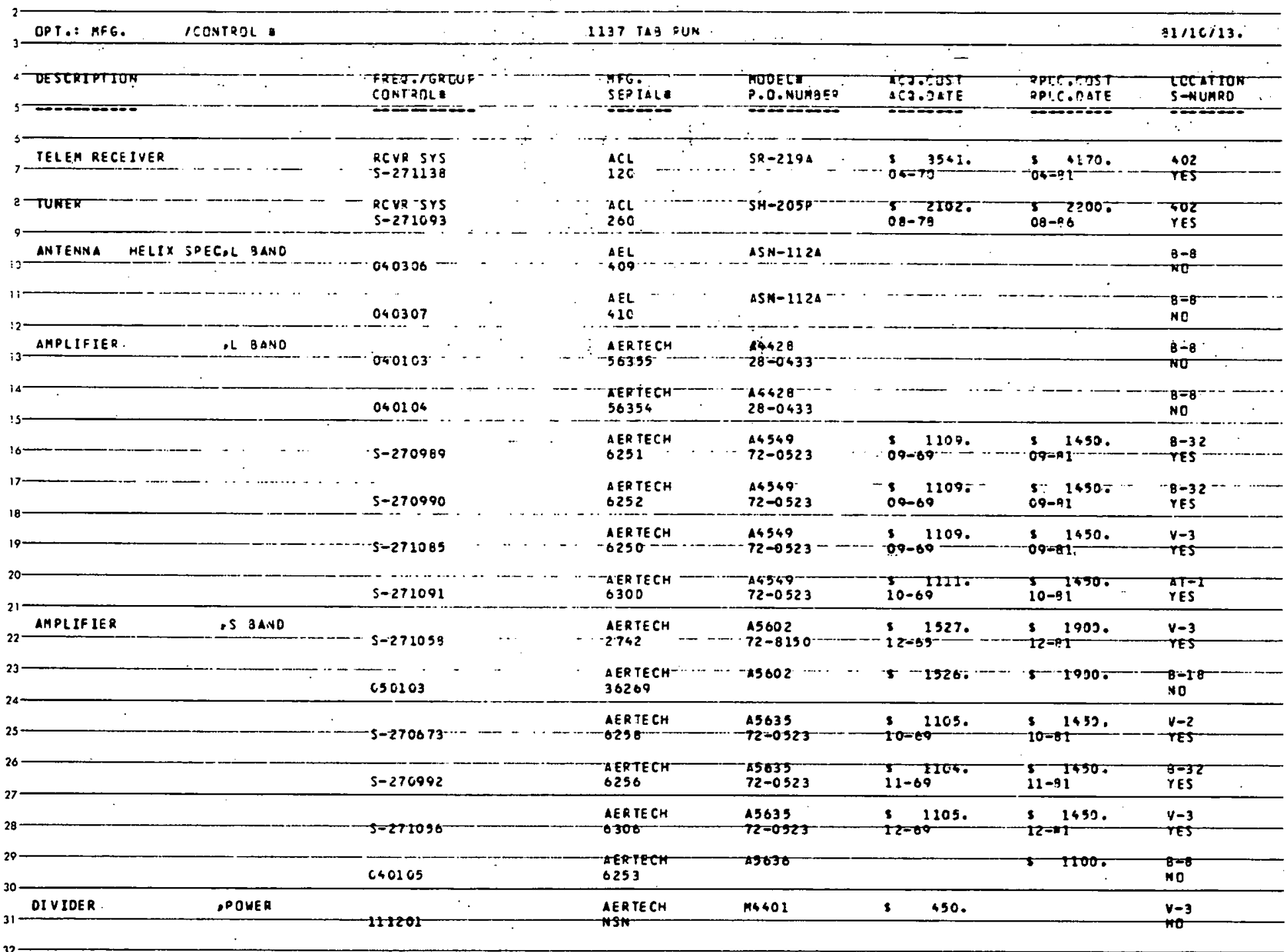

a. Example of Format of Full Inventory Tab Run Sorted by Manufacturer/Control Number 


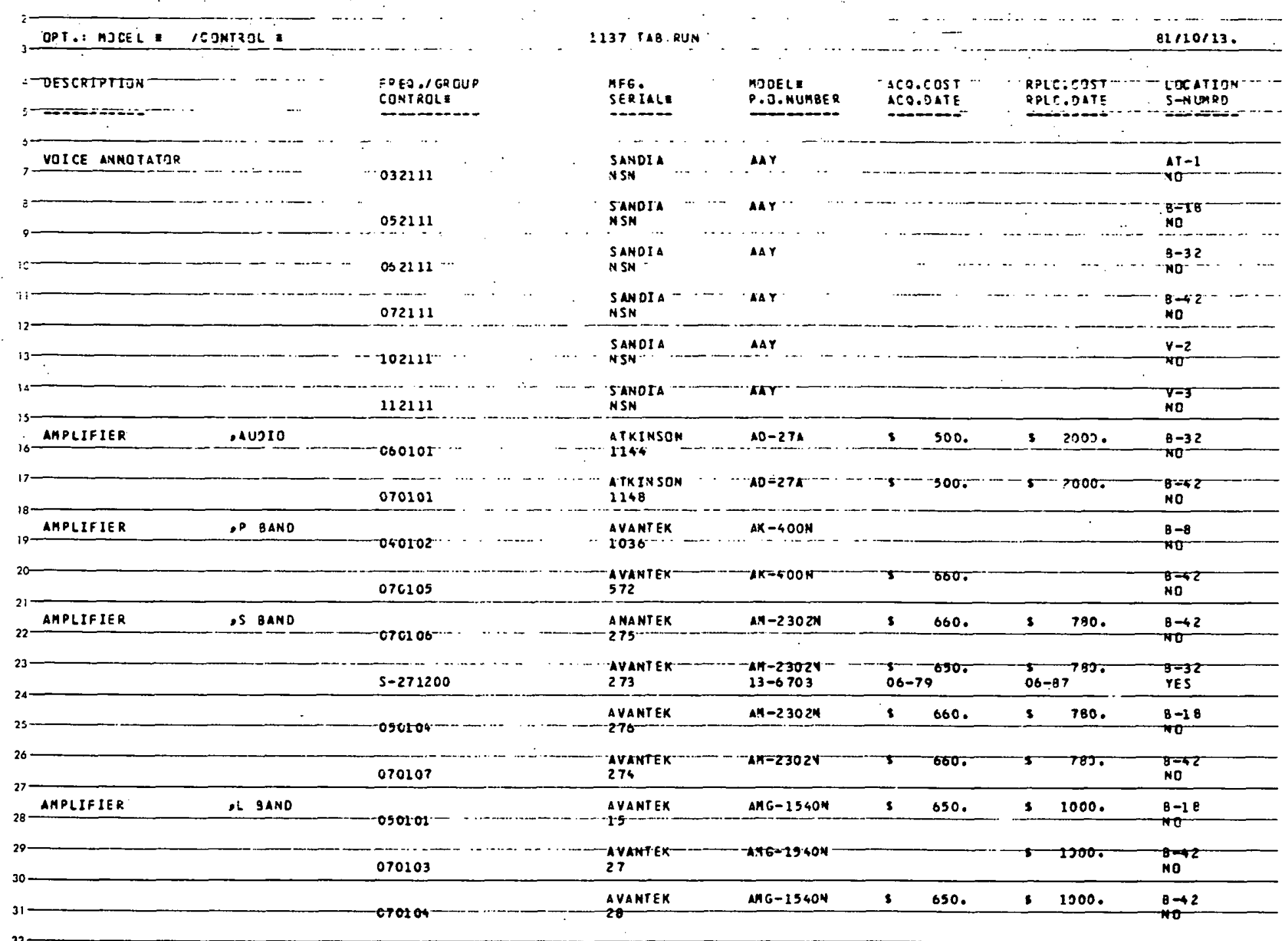

b. Example of Format of Full Inventory Tab Run Sorted by Model Number/Control Number 


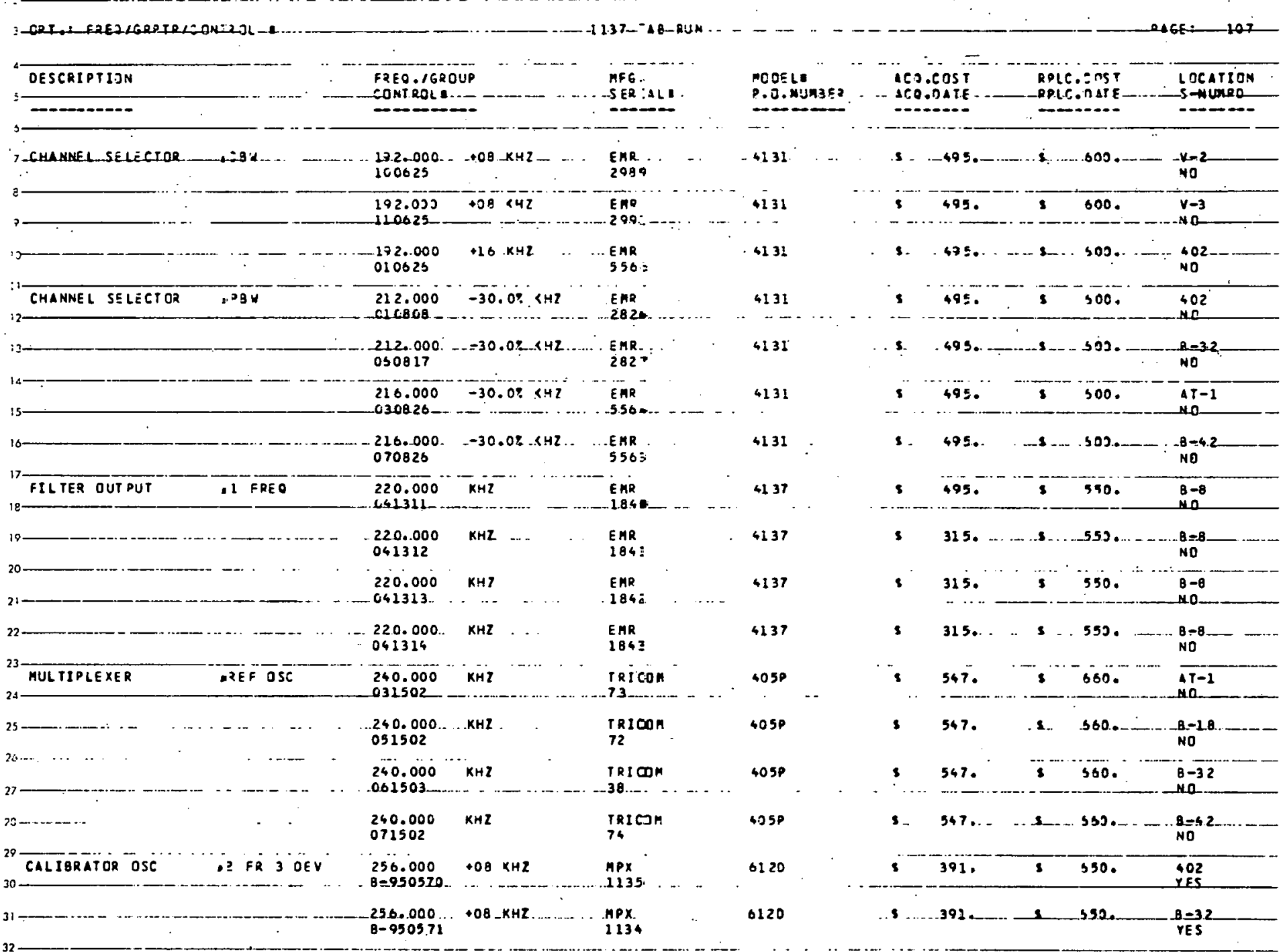

c. Example of Format of Full Inventory Tab Run Sorted by Frequency or Group/Control Number 


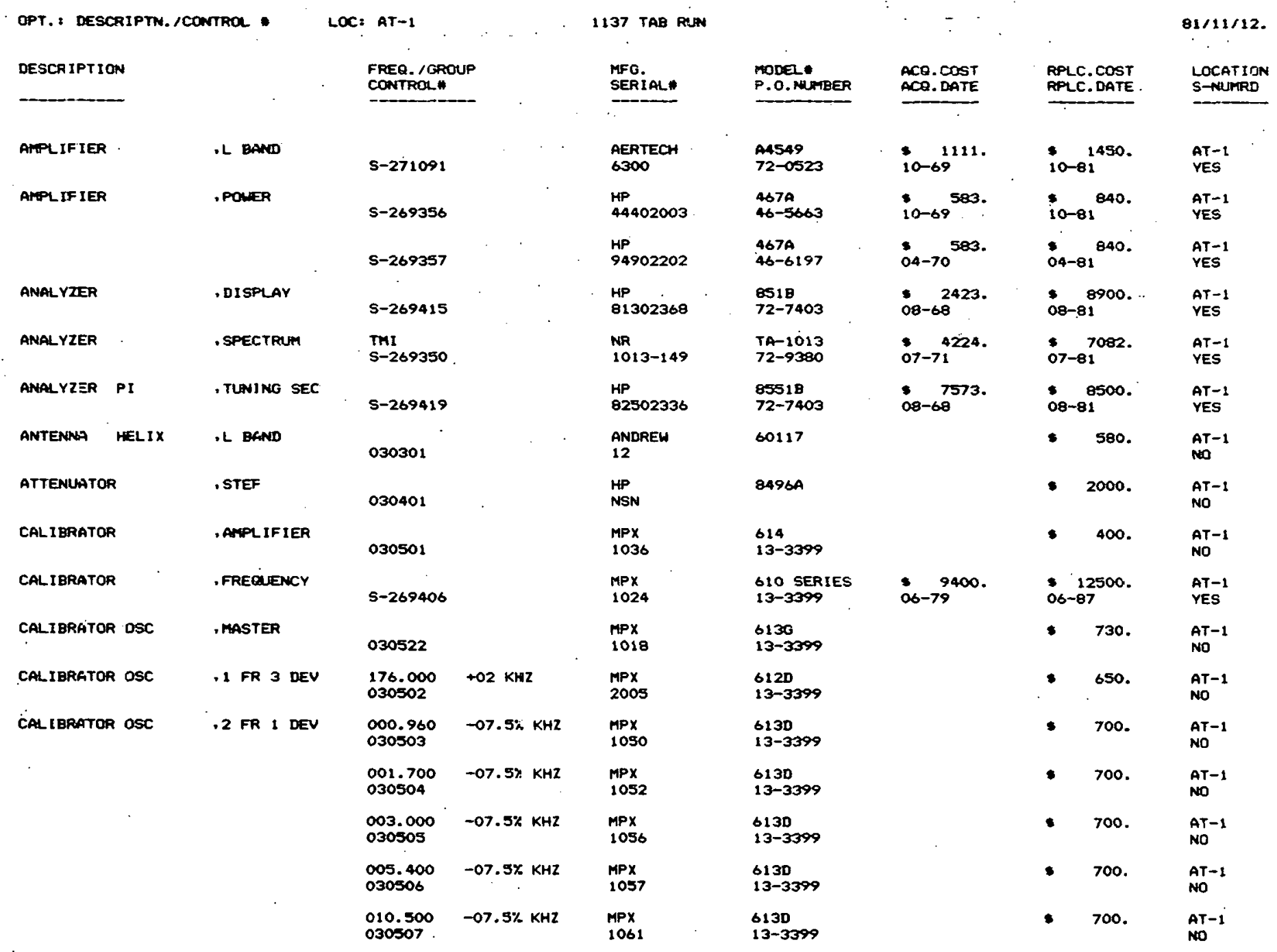

d. Format of Full Tab Run Sorted by Description and Control Number for Location AT-1 Only 
APPENDIX D

Examples of Full Inventory Search Tab Runs for Various Locations 
SEARCH ONI

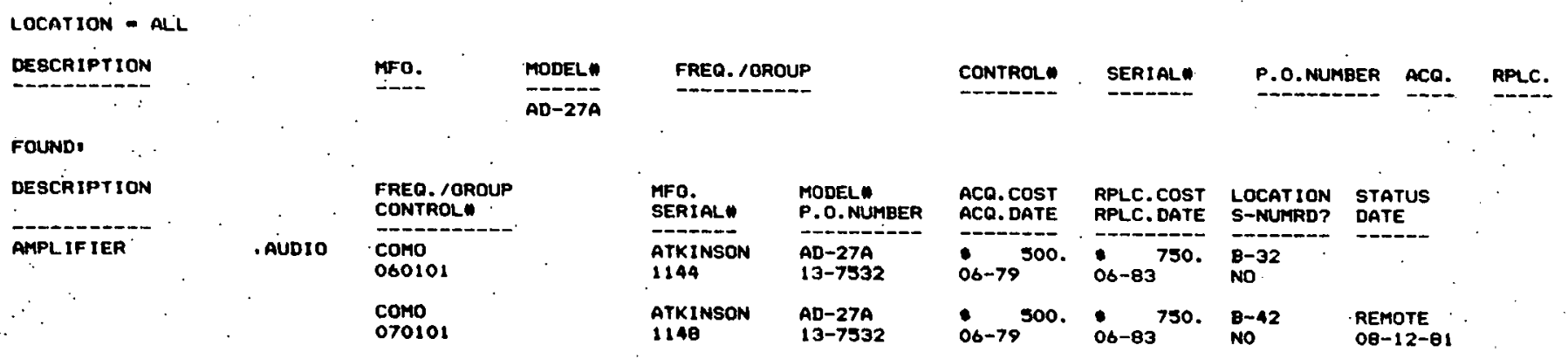

END OF SEARCH.

neadr:

a. Example of Format of Full Inventory Search by Model Number: AD-27A

SEARCH. ON:

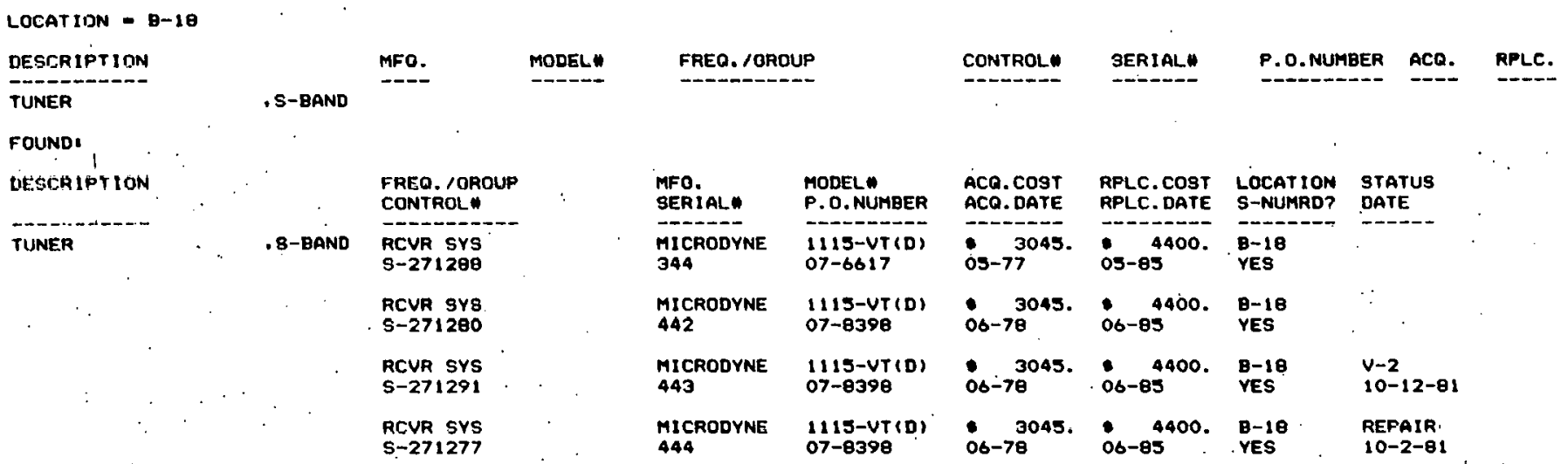

END OF SEARCH.

READY.

h. Wxample of Format of Full Inventory Search for Items in Location B-18 of Description: Tuner, S-Band

SEARCH ON:

LOCATION - ALL

DESCRIPTION

.

\begin{tabular}{lll} 
MFO. & MODEL \\
\hline EMR & 410 & FREO. IGROUP
\end{tabular}

CONTROL SERIAL" P.O.NUMBER ACQ. RPLC.

FŨUnuเ

DEBCRIPTION

-

FREO. /GROUP CONTROL

DISCRIMINATOR ,VARIBLE
EMR

153

165

s-270702

s-271183

5-271083

s-270900

s-269381

$5-271221$
165

186

EHR

226

ENR

227

EMR
228

EMR
P.O. NUMBER

410

U'A-j'syy

$41 v$

02-3299

410

410

$07-8352$

410

$99-9999$

410

27-8399

410
$07-8286$

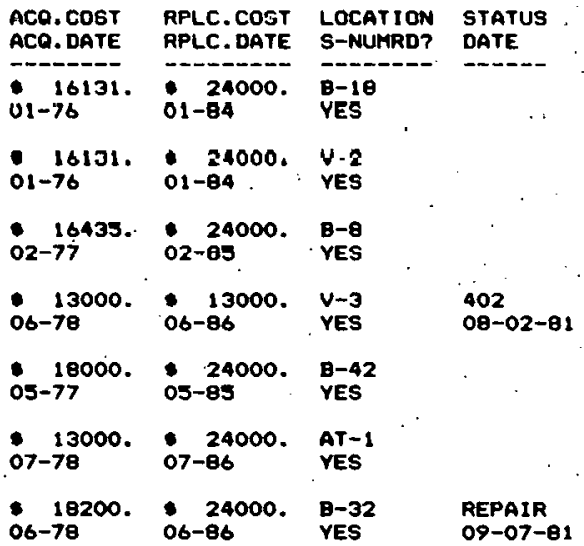

END OF SEARCH.

READY.

c. Example of Format of Full Inventory Search for All Units of an Item Made by a Particular Manufacturer: EMR, Model 410 


\section{APPENDIX E}

\section{Division 1137 Property Movement Form}




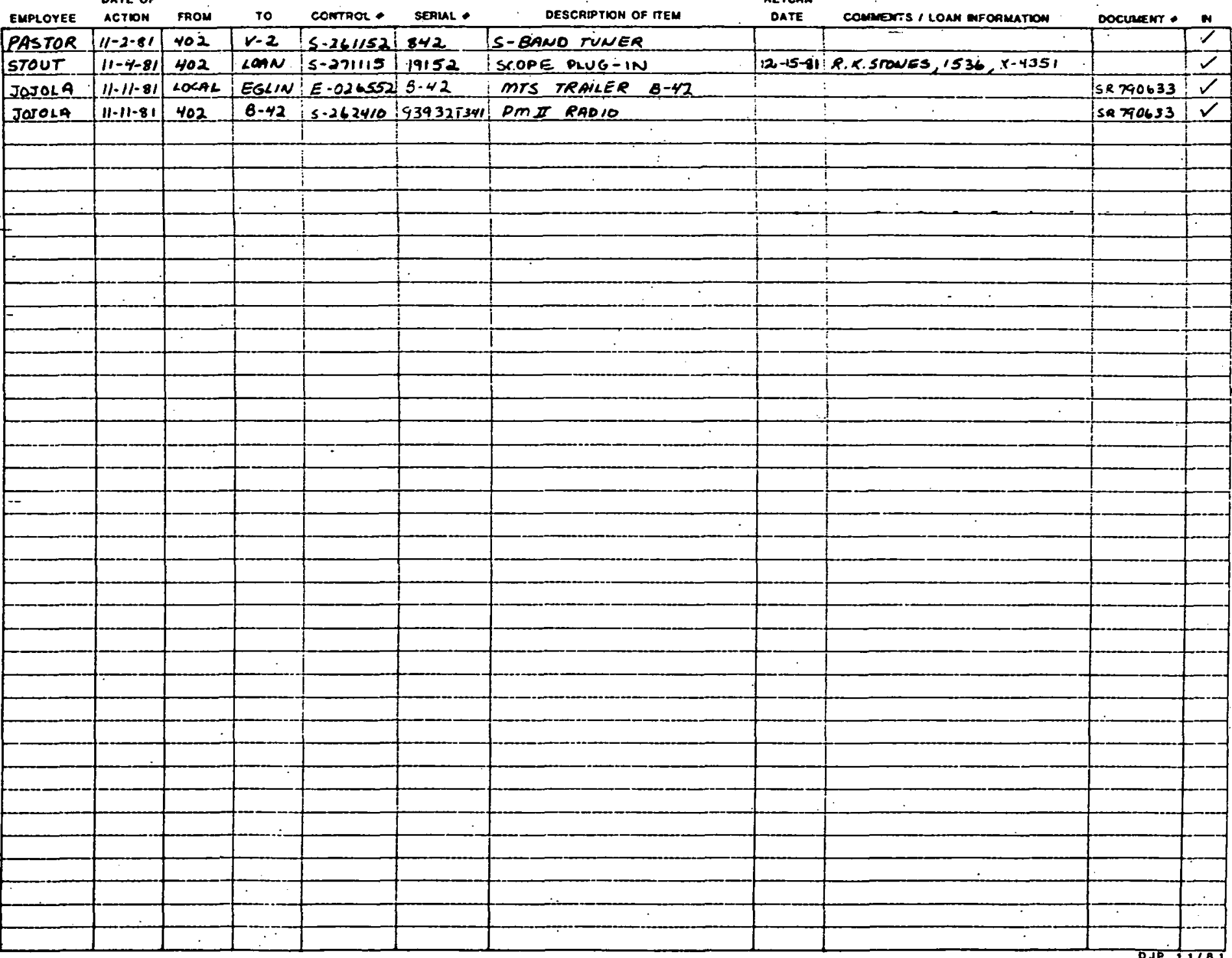




\section{APPENDIX F}

\section{Examples of Errors Discovered by the Movement Fill Routine}




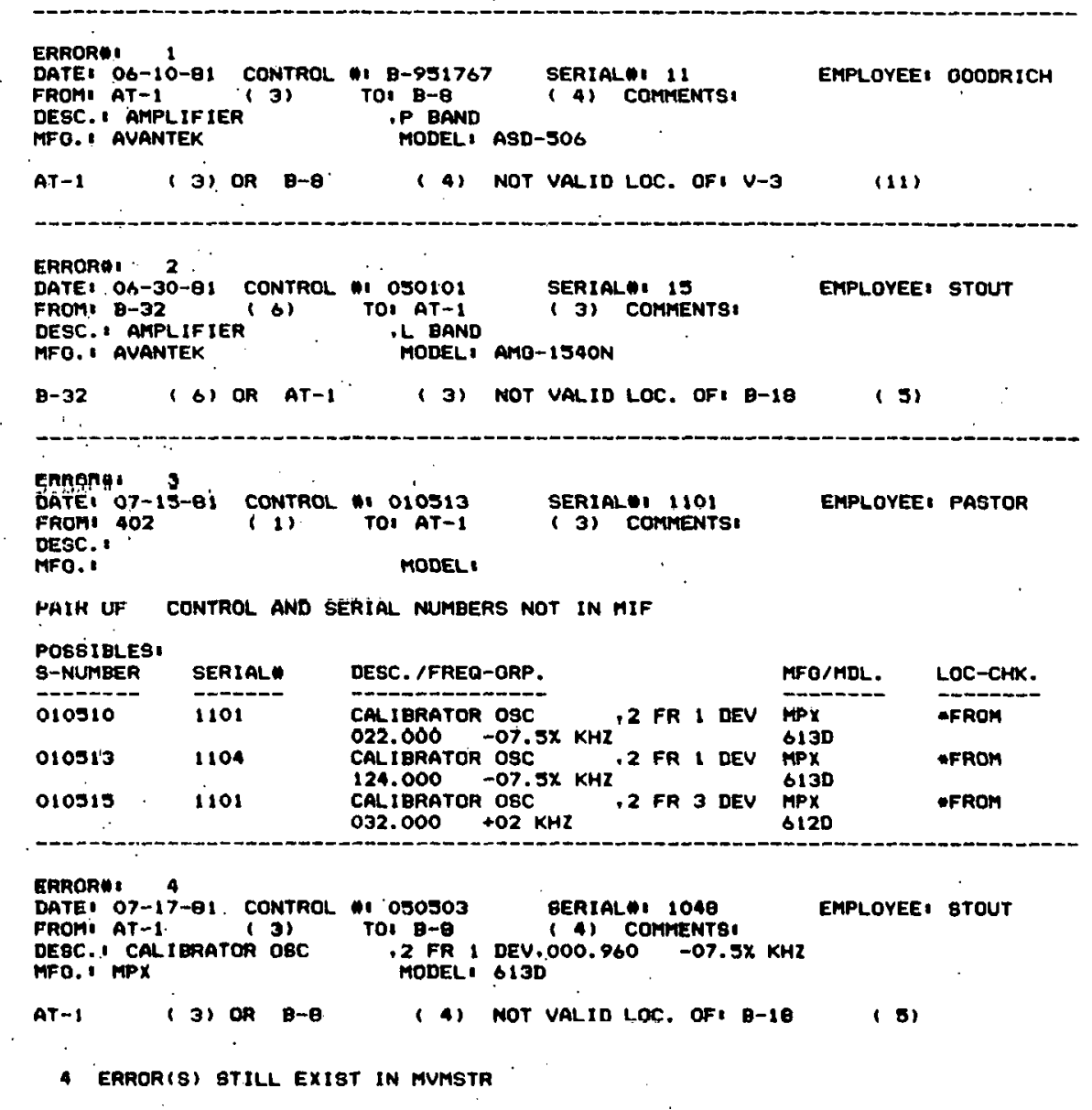

Cumments (Not Part of 1.isting)

This item belongs in location $v+3$ hut was moved from AT.1 to B.8. A possible error move outside of valid Incation of $\mathrm{V} \cdot \mathbf{3}$.

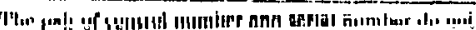
exist in the maxter inventory file. Pongaitlea fullow: 1.(11:-(:HK tells to/from lixation is the same as the assigued. 


\section{APPENDIX G}

\section{Listings for Various Movements of Equipment}


DESCRIPTION SCOPE PI - DUAL tRace TEKTRONIX $\frac{\text { MODEL }}{\text { TAZS }}$ FPEQ I IGROIPP CONTROL-: SERIAL . LOCATION

\section{EMPLOVEE}

MOVED TO

EQPT. ERRPOP:

RTN. DATE

COMMENTS:

EVENT STAT

10-22-81

STOUT

AT -1

B-8

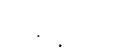

10-25-81 PASTOR

11-02-81 PASTOR

C -22

402

IAACTIVE

IMACTIVE

$11-19-81$

JOJOLA

402

AT -1

Imact IVE

IRACTIVE

12-03-81 MOFFMAN

E-32

12-10-81

STOUT

B-8

$8-8$

AT-1

INACTIVE

ACTIVE

a. Movement Search for History of all Moves on One Item for Starting Date of 10-1-81. 
START DATE: 01-01-81

DESCFIPTION

DATE MOVED

MOVED FROM

MOVED TO

RFr. ERPLOYE

MODEL *
RETRN. OATE

Hoffman

8820A

$\underset{06-09-81}{\text { AMPLIFIER }}$ B-18 . LOW GAIN

AMPLIFIER
Ob-10-81 AT-1 IP BANE-8

, REF $0 S-8$

CALIBRATOR OSC
$07-15-81$ $402 \quad$, 2 FR 1 DET

CALIBRATUR OSC
$07-17-81$ , 2 FR 1 1 DEV

CONVERTEF:
O7-17-81 AT-1 FREQUEVCY
B-8

CALIBRATCR OSC
$07-18-81$ AT-1 2 FR $\begin{gathered}3 \text { DEV } \\ \text { B-18 }\end{gathered}$

MTS
$07-19-81$ LOCAL ARECHILE

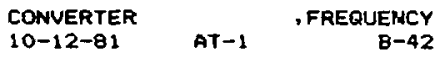

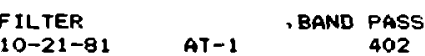

CALIBFATOR OSC
$10-22-81$ AT-1 2 FR 3 DEV

TIME DODE TRANS

8-18

B-18

$\underset{10-25-31}{\text { CALIBRATOR OSC }}$ O-18. 2 FF $\underset{B-32}{1}$

POWER SUPFLY AT-1
$10-30-81$

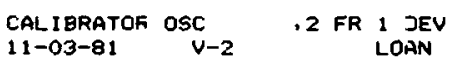

SCOPE PI

DUAL TRACE
AT -1
AVANTEK ASO ASD-5O6

TRICOM : $405 P$

TRICOM
PASTOR

MPX
PASTOR

MPX
STOUT

MICRODYNE

MPX
PASTOR

SANDIA

MICRODYNE

MICRODYNE
PASTOR

MICRODYNE

MPX

DATUM

MPX

MPX

PAPTOR

MPX
PASTOR

TEKTRONIX
STOUT

6130

62288

$11-05-81$

$7 A 26$
$240.000 \quad \mathrm{KHZ}$

$124.000 \quad-07.5 \% \mathrm{KHZ}$

$000.960 \quad-07.5 \% \mathrm{KHZ}$

RCVR SYS

$256.000 \quad+08 \mathrm{KHZ}$

MTS

RCUR SYS

RCVR SYS

$048.000+02 \mathrm{KHZ}$

$003.000 \quad-07.5 \% \mathrm{KHZ}$

b. All Active Moves Pending from 1-1-81. 
- all listingos DESCRIPTION DATE MOVED Date noved DISCRIMINATOR
10-16-81 T-46 CALIBRATOR OSC
IO-17-81 SCOPE PI
$10-22-81$ RECORDER DIGITAL 0-26-81. B-8 SCOPE PI
$11-19-81$

Sc00E $11-28-81$ 8-8 SCOPE PI
$12-03-81 \quad 8-32$ SCOPE PI B-8

\section{ETPRO}

RODEL : DATE

FREQ. /GROUP
COMVENTS ON LOAN/MONEMENT

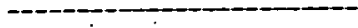

EMR $4: 130$

MILLER

PAX

TEKTRONI

STOUT

FEFTEC

TEKTRONI

J.JOLA

TEKTRONIX ZA26

TEKTRONIX

HOFFMAN

TEKTRON
STOUT
$022.000 \quad-07.5 \times \mathrm{KHZ}$

$t 130$

ADPE

1884049

-A26

TA26

TA2B

c. All Movements Into or Out of Location B-8 Starting 1-1-81.

01/11/12.

CONTROE: * SERIAL *
ASSGN.LOC. EVENT STAT

$\begin{array}{ll}5-271099 & \text { ISSS } \\ 0-8 & \text { INACTIVE }\end{array}$

$\begin{array}{ll}100505 & 1027 \\ V-2 & \text { INACTIVE }\end{array}$

S-271125. B193152
B-8 INACTIVE

S-269305 391512847

AT-1.

S-271112
B-8

S-271115. 8193152

B-8 INACTIVE

S-271115 B19:152

$\underset{B-8}{S-271115 \quad \text { BCTIVE }}$ 


\section{APPENDIX H}

Example of Format of Tab Run Listing All Items in a Single Location (Shipper Format) 


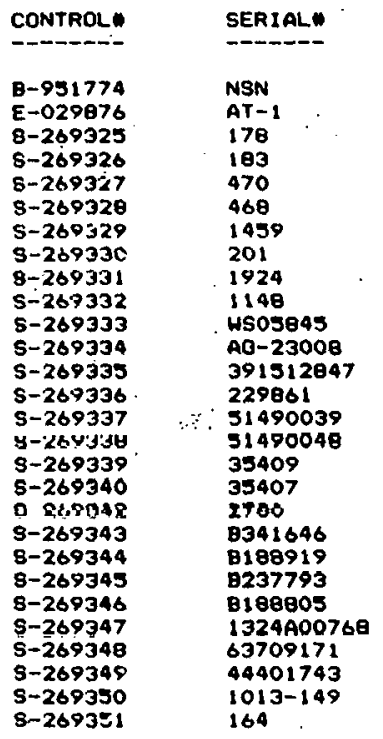

\section{DESCRIPTION}

SCOPE CAMERA

MTS

TUNER

TUNER

TUNER

TUNER

DISCRIMINATOR
DISCRIMINATOR

DISCAIMINATOR

TIME CODE TRANS

DISC

COMPUTER

RECORDER DIOITAL

PERFORATOR/READER

SELECTOR

DEĆÓTIIUUTATOR

FILTER

i I ITE LUUL UEN/IKANG

SCOPE

SCOPE PI

SCOPE. PI

SCDPE PI

SCDPE PI

METER

METER

METER PI

ANALYZER
SYNCHRONI ZER

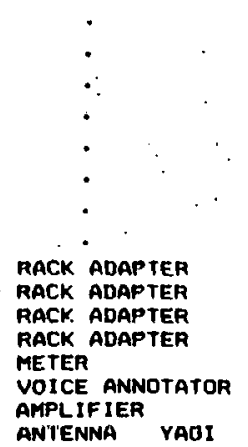

ANIENNA YAOI

163
1915
1602
478
275
NSN
15
NSN

ITEM COUNT: 251.

valuei 719686.

DIBAC.
DISC.
igIBC.
i MUX
iPOWER
iL BAND
iP BAND

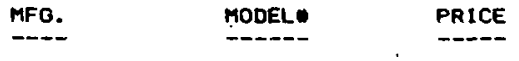

POLAROID CR9

MICRODYNE IIIA-VT(D): 4700

MICRODYNE 1114-VT(D) 1700

MICRODYNE 1112-VT(D) 3300

MICRODYNE $\quad$.1112-VT(D) . 3300

2005

EMR 4130 2005.

EMR 4130 2005.

DATUM 9200 4100.

DEC RXO2 3900 .

DEC PDP11/34 40000

PERTEC TB840A9 10000

REMEX RAF6075BB 3900 .

กS1 7113 .

DS1 7101 30200.

ITHACO. 4213 : 2422

ITHACQ 4213

TEKTRONIX 71003

TEKTRONIX 7603 3000.

TEKTRNIX 7A26 1700

TEKTRONIX TA13

TEKTRONIX 7B53A

$\begin{array}{llll}\text { MF } & \text { S340A } & 6000 . \\ \text { HP } & 3440 A & 1400 .\end{array}$

MP $3441 A$

NR TA-1013

EMR 315 : 2550 .

$\begin{array}{llrr}\text { EMR } & 4005 & \bullet & 1000 . \\ \text { EMR } & 4005 & : & 1000 . \\ \text { EMR } & 4005 & : & 1000 . \\ \text { TRICOM } & 401-267 & & 0 . \\ \text { PHILCO } & 1648 & 0 . \\ \text { SANDIA } & \text { AAY } & & 0 . \\ \text { AUANTEK } & \text { AMO-1540N } & -1000 . \\ \text { TACO } & Y-53 & & 0 .\end{array}$

LAST ENTRY IN MUFILE: 09/04/81 


\section{APPENDIX I}

\section{Block Dump Inventory}


STATUS: HSTR ${ }^{1}$-CONTRC. ${ }^{2}$ DATE: 07-:9-81 ${ }^{1}$ AT-1 TAB RLW (E-O2987b)

DESCRIPTION

AMPLIFIER

AMPLIFIER

ATPLIFIER

ANALYZER

ANALYZER

ANALYZER PI

ANTENNA HELIX

ANTENNA YAGI

ATTENUATOR

CALIBRATOR

CAL IBRATOR

CAL IBRATOR OSC

CALIBRATOR OSC

CALIBRATOR OSC
FREQ. IGROUP

conrtra.

$5-271091 \quad 6300 \quad \& \quad 1450$.

050101 15 1000. 06-30-81 *18-18

$5-270966$ 1828000472 \& 1580 . $06-09-81 \rightarrow B-32$

$s-269556$

$5-269357$

$5-269415$

$5-269350$

S-269419

030301

100304

030401

030501

s-269406

030522

- FREQuency mP

- master mo

II FR 3 DEV MPX

. 2 FR 1 DEV MPX

$\operatorname{mx}$

$\operatorname{mx}$

$\operatorname{mx}$

rox:

610 SERIES

6130

6120

6130

6130

6130

6130

6130 $176.000+\infty \mathrm{KHz} \quad 030502$

$000.960 \quad-07.5 \%$ KHZ 030503

$\$ 01.700 \quad-07.5 \% \mathrm{KHZ} \quad 030504$

$003.000 \quad-07.5 \% \mathrm{KHZ} \quad 030505$

$005.400 \quad-07.5 \%$ KHZ 030506

$010.500 \quad-07.5 \times \quad K H Z \quad 030507$
44402003 \& 840.

94902202 . 840.

81302360.8900

$1013-149 \div 7082$.

82502336 ( $8500.09-04-81>0-18$

$12^{\circ} 580$.

NSN 09-04-81 $\cdot v-2$

NSN 2000.

10364400

$1024 \quad 12500$

$1018 \quad 730$.

$2005 \quad 650$.

$1050 \quad 700$.

$1052 \quad 700$.

$1056 \quad 700$.

$1057 \quad 700$.

$1001 \quad 700$.

- - from aniother assi jned location 3

* a fRom another non-7SSigned locat don 9

AMP-CAL

AT-1 - 1

*Not part of tab run. 


\begin{tabular}{|c|c|c|c|c|c|c|c|c|c|}
\hline DESCRIPTION & & ro: & noder. & FREO. I GAOUP & contrace. & seriace & $\cos T$ & N. DATE & STATUS \\
\hline TEEA RECEIVER . & & MICRODVIVE & $11000 R$ & RCVR SYS & $s-269499$ & 1611 & 9100. & & \\
\hline TIFE CODE CEN/TRANK & & DATUM & 9300 & & $s-269342$ & 2780 & $\$ 100$ & & \\
\hline TITE CODE Trans & & DATUM & 9200 & & $5-269302$ & 1340 & $\$ 100$ & & \\
\hline & & DATUA & 9200 & & $5-269302$ & 1757 & 4100 & & \\
\hline TUNER & iL BAND & MICRODYNE & $1114-V T(D)$ & RCVR SYS & $s-269325$ & 278 & 4700. & & \\
\hline & & . Arcroone & 1214-VT(D) & RCVR SYS & $5-269326$ & 183 & 4700. & . & \\
\hline TUNER & IP BAND & MICroone & $1112-V T(D)$ & RCVR SYS & $5-269327$ & 470 & 3000 . & & \\
\hline & & MICRODYNE & 1112-vTCD) & RCVR SYS & $5-2693208$ & 460 & 3300 & & \\
\hline TUNER & is Band & microonve & 1115-VT(D) & RCVR SYS & $5-269304$ & $3055^{\circ}$ & 4400. & & \\
\hline & & Mrcroone & $1113-v T(D)$ & ACVR SYS & $5-269399$ & 571 & 4400. & & \\
\hline & . & MICRODYNE & $1115-V T(D)$ & RCVR SYS & $5-269403$ & 341 & 4400. & & \\
\hline & & MICRODVE & $1115-v T(D)$ & RCVR SYS & $s-269752$ & 560 & 4400 & & \\
\hline VOICE ANASOTATOR & & SANDIA & AAY & & 032111 & MSN & & & \\
\hline
\end{tabular}

LINE CONMT: 2535 ITEN COUNT: $251 .^{6}$ TOTAL REPLACEMENT COST: 719686.

LAST ENTRY IN MUFILE, OQ/OA/81

- Fron another assiched location

* - From another nON-ASsigived location

TEL VOI

AT-1 $\quad-13$

* Not part of tab run. 
Notes (not part of listing):

1. Location of all items as of this date (AT-1 located at White Sands Missile Range on date shown).

2. Listing order for like description.

3. Shown is location both moved from and assigned to that item.

4.. Shown is location assigned to that item, moved in from a nonassigned location.

5. Number of entries.

6. Actual number of items at Location AT-1 as of listing date (indicates two items listed are not presently at this location). 


\section{DISTRIBUTION:}

1100 (C. D. Broyles

1120 -'1. 1. Pace

1137 (i. 1. Miller (35)

1170 S. A. Moore

1171 D. H. Denton

1172 R. D. Bentley

1173 L. W. Lathrop

2627 D. A. Young

3411 N. W. Ollman

3412 M. E. Mefford

3413 J. A. Kaiser

3416 E. C. Domme

8214 M. A. Pound

3141 L. J. Erickson (5)

3151. W. L. Garner (3)

3154-3 C. H. Dalin (25)

For: DOE/TIC (Unlimited Release) 


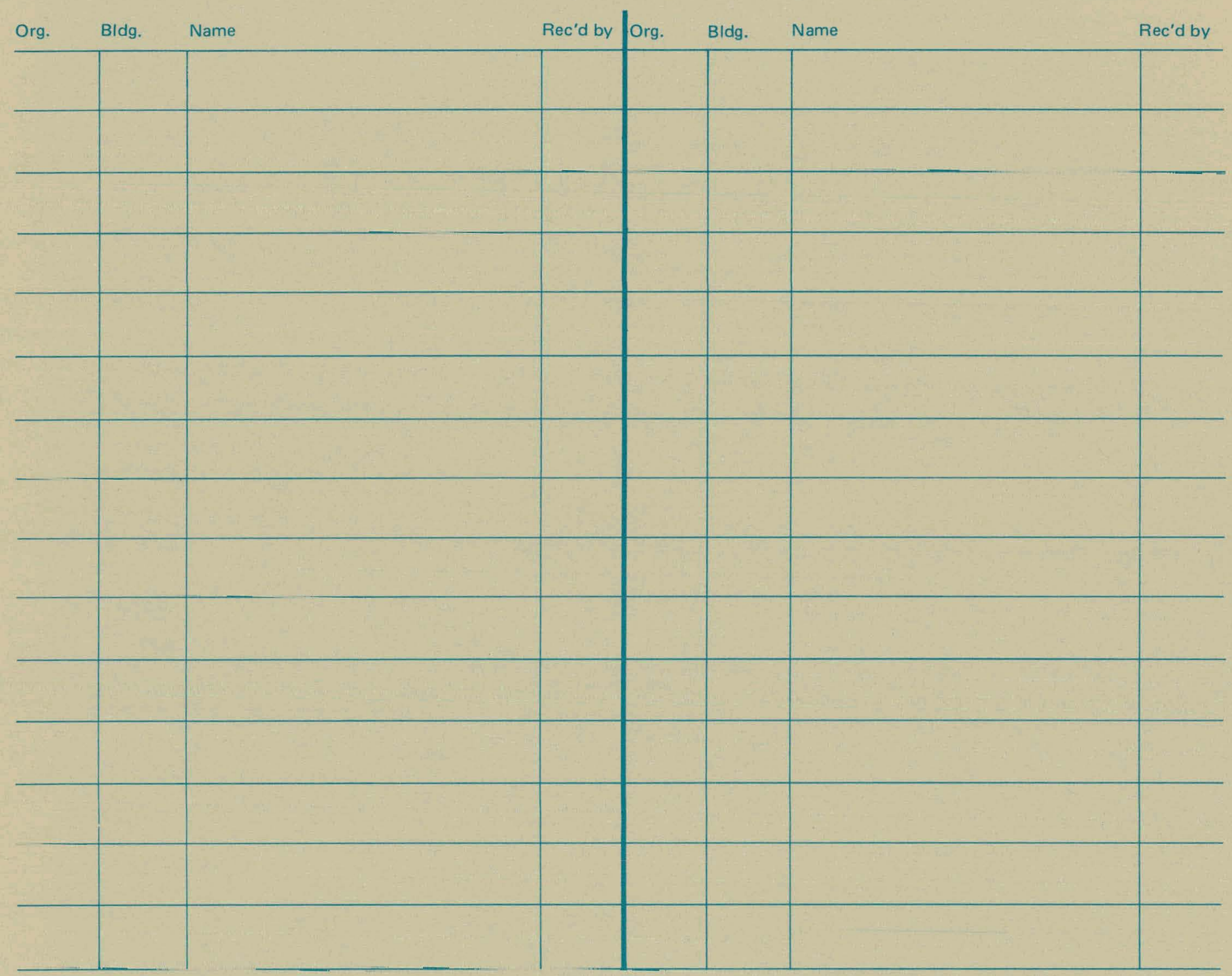

